\title{
Pengaruh Senam Prenatal Yoga terhadap Penurunan Kecemasan Ibu Hamil Trimester III
}

\author{
Influence of Yoga Prenatal Gym to Decreasing in Anxiety of Third \\ Trimester Pregnant Women \\ Ashari, Gabriellyn Sura Pongsibidang, Andi Mikhrunnisai \\ Program Studi D-III Kebidanan Akademi Kebidanan Gunung Sari Makassar \\ (asharimasse889@gmail.com)
}

\begin{abstract}
ABSTRAK
Kecemasan merupakan suatu perasaan khawatir yang erat kaitannya dengan keadaan perasaan yang tidak pasti atau tidak berdaya, serta keadaan emosi yang belum jelas objek spesifiknya. Keadaan cemas banyak terjadi pada ibu hamil yang telah mendekati masa persalinan. Penelitian ini memiliki tujuan untuk mengetahui pengaruh senam prenatal yoga terhadap penurunan kecemasan ibu hamil trimester III di Puskesmas Pattingalloang dan Puskesmas Tamalate Kota Makassar. Jenis penelitian yang digunakan termasuk penelitian eksperimen semu (quasy experiment) dengan rancangan yaitu non-randomized pre test post test with control group design. Teknik pengambilan sampel secara purposive sampling. Sampel dalam penelitian ini sebanyak 120 ibu hamil yang dibagi atas 2 grup, yaitu grup I (kelompok intervensi) sebanyak 60 ibu hamil dan grup II (kelompok kontrol) sebanyak $60 \mathrm{ibu}$ hamil. Analisis data yang dilakukan dalam penelitian ini berupa analisis univariat dan analisis bivariat. Hasil penelitian menunjukkan hubungan yang signifikan antara intervensi senam prenatal yoga dalam menurunkan kejadian kecemasan pada ibu hamil trimester III di Puskesmas Pattingalloang dan Puskesmas Tamalate Kota Makassar dengan nilai $\mathrm{p}=0,000$. Kesimpulan penelitian ini menunjukkan bahwa senam yoga pada tahap prenatal memiliki pengaruh terhadap turunnya kejadian kecemasan pada ibu hamil.
\end{abstract}

Kata kunci : Prenatal yoga, kecemasan, ibu hamil

\section{ABSTRACT}

An anxiety is a feeling of worry associated with feelings of uncertainty or helplessness and an emotional conditions that is not yet clear about its specific object. Anxious conditionsoccurs a lot in pregnant women who have approached delivery period. This study aims to know influence of yoga prenatal gym to decreasing in anxiety of third trimester pregnant women in pattingalloang community health center and tamalate community health center makassar city. the type of research used included quasi experiment with a design that is the nonrandomized pretest posttest with control group design. This sample of study was 120 pregnant women that was divided 2 groups, namely group I (intervention group) for 60 pregnant women and group II (control group) for 60 pregnant women. Data analysis was univariate and bivariate analysis. The results showed a significant relationship between yoga prenatal gym intervention in reducing the incidence of anxiety in third trimester pregnant women in Pattingalloang Health Center and Tamalate Health Center Makassar City with a value of $p=0,000$. The conclusion of this study shows that yoga exercises at the prenatal stage have an influence on the decline in the incidence of anxiety of pregnant women.

Keywords : Yoga prenatal, anxiety, pregnant women 


\section{PENDAHULUAN}

Kecemasan berkaitan dengan keadaan khawatir berupa rasa takut atau perasaan yang tidak pasti maupun tidak berdaya, serta keadaan emosi yang belum jelas akan objek spesifiknya. Pada kehamilan pertama ketakutan ini sering dirasakan terutama dalam menghadapi persalinan. Beban psikologi pada seorang wanita hamil, lebih banyak terjadi pada umur kehamilan trimester III. Wanita yang mengalami kecemasan sewaktu hamil akan lebih banyak mengalami persalinan abnormal bahkan dapat berkomplikasi pada kematian ibu dan janin. ${ }^{1}$

Kejadian kematian ibu hamil serta kesakitan pada ibu hamil tetap menjadi masalah yang besar di negara berkembang. WHO memperkirakan setiap hari di seluruh dunia terdapat sekitar 830 wanita meninggal karena kehamilan dan persalinan serta 99\% kematian ibu terjadi di negara berkembang. ${ }^{2} \mathrm{Di}$ Indonesia, AKI mengalami penurunan dari 359 per 100.000 jumlah kelahiran hidup yang terjadi tepat pada tahun 2012 menjadi 305 per 100.000 jumlah kelahiran hidup di tahun 2015. Meskipun terdapat penurunan, AKI di Indonesia belum mencapai target Pembangunan Jangka Panjang Bidang Kesehatan 2005-2025, yaitu dapat diturunkan menjadi 74 per 100.000 kelahiran hidup. ${ }^{3}$

Data Provinsi Sulawesi Selatan pada tahun 2013 jumlah kematian ibu mengalami kenaikan dari 78,38 per $100.000 \mathrm{KH}$ menjadi 99,38 per $100.000 \mathrm{KH}$ pada tahun 2015. Kejadian kematian ibu di Provinsi Sulawesi Selatan pada tahun 2017 mengalami penurunan menjadi 115 kasus dibandingkan tahun 2016 sebesar 156 kasus kematian ibu. Kota Makassar mencatat Angka Kematian Ibu (AKI) tahun 2013 adalah 16,28 per 100.000 KH dan meningkat menjadi 19,86 per 100.000 KH pada tahun 2015, sedangkan di Puskesmas Pattingalloang dan Puskesmas Tamalate masingmasing terdapat satu kasus kematian ibu pada tahun 2015. ${ }^{4}$ Kejadian kematian ibu pada tahun 2016 sampai 2017 tidak terjadi di Puskesmas Tamalate, tetapi pada Puskesmas Pattingalloang hanya terjadi pada tahun 2017 sebanyak satu kasus kematian ibu. ${ }^{5,6}$

Cara yang efektif dalam menanggulangi masalah yang berkaitan dengan masih tingginya angka kematian ibu hamil serta kesakitan ibu hamil yang dipicu oleh kecemasan adalah dengan melakukan latihan fisik, seperti meditasi/yoga. Berlatih senam prenatal yoga merupakan solusi yang tepat untuk menolong ibu hamil sendiri yang bisa membantu dalam proses kehamilan, kelahiran dan bahkan memudahkan kegiatan pengasuhan anak nantinya yang bisa didapat dengan mengikuti kelas antenatal. Senam yoga pada tahap prenatal ibu hamil membantu fokus ibu hamil terhadap pengaturan ritme nafas, yang tetap berfokus pada perasaan nyaman, aman dan tenang yang dirasakan ibu hamil dalam berlatih. ${ }^{7}$

Latihan yoga yang dilakukan diantaranya mencakup berbagai relaksasi, mengatur postur, olah napas dan meditasi selama satu jam setiap hari. Gerakan relaksasi, mengatur postur dan olah nafas ini sama dengan gerakan yang dilakukan pada saat senam hamil, karena teknik gerakannya menitikberatkan kepada latihan otot-otot. Bentuk meditasi yang dilakukan selama senam ini yaitu berupa imaginasi terbimbing, ibu hamil dianjurkan mengatur posisi yang paling relaks, kemudian diminta untuk memejamkan mata dan mengikuti imaginasi yang diarahkan oleh petugas. ${ }^{8}$

Hasil penelitian dari Apriliani mengemukakan bahwa cara berpikir positifyang dibangun oleh ibu hamil terkait persalinan adalah salah satu bentuk manfaatyang didapatkan dari senam yoga pada tahap relaksasi yang dalam. ${ }^{9}$ Relaksasi ini diharapkan menghindarkan ibu hamil dari seperti tegang maupun rasa cemas dan rasa takut terkait persalinan dapat dihilangkan dan memunculkan perasaan optimis serta berani untuk melalui proses alamiah yang akan dilewati oleh perempuan. Penelitian sebelumnya yaitu Battledi Amerika Serikat, Bershadsky di California Selatan, dan Kinser di Virginia menemukan bahwa intervensi senam prenatal yoga pada wanita hamil efektif dalam mengurangi kecemasan pada ibu hamil. ${ }^{10-12}$ Pada penelitian sebelumnya hanya fokus pada intervensi senam prenatal yoga saja, sedangkan dalam penelitian ini disertai dengan penyampaian informasi tentang pentingnya senam yoga pada ibu hamil dengan menggunakan media komunikasi berupa leaflet dan video. Oleh karena itu, peneliti tertarik untuk mengetahui pengaruh senam yoga pada tahap prenatal terhadap turunnya kejadian kecemasan pada ibu hamil Trimester III di Puskesmas Pattingalloang dan Puskesmas 
Tamalate Kota Makassar.

\section{BAHAN DAN METODE}

Jenis penelitian ini masuk dalam kelompok penelitian eksperimen sетu (quasy experiment) dengan rancangan yaitu the non randomized pre test post test with control group design. Lokasi penelitian ini meliputi dua tempat yang berbeda, yaitu di Puskesmas Pattingalloang dan Puskesmas Tamalate Kota Makassar. Populasi penelitian ini mencakup semua ibu hamil yang telah masuk pada fase trimester ketiga dan terdaftar dalam wilayah kerja Puskesmas Pattingalloang serta Puskesmas Tamalate Kota Makassar pada tahun 2018. Sampel adalah sebagian ibu hamil Trimester III yang terdaftar dalam wilayah kerja Puskesmas Pattingalloang dan Puskesmas Tamalate Kota Makassar. Sampel penelitian ini diambil secara purposive sampling hingga didapatkan sampel sebanyak 120 ibu hamil yang dibagi menjadi 2 grup, yaitu grup I (kelompok intervensi) sebanyak 60 ibu hamil yang mendapatkan intervensi senam prenatal yoga dan grup II (kelompok kontrol) sebanyak 60 ibu hamil yang tidak mendapatkan intervensi senam prenatal yoga, tetapi diberi media komunikasi berupa leaflet terkait penurunan kecemasan ibu hamil. Pelaksanaan intervensi dilakukan sebanyak dua kali di masing-masing puskesmas yang dipimpin oleh instruktur yoga yang telah terlatih. Intervensi pertama dilakukan pada akhir bulan Mei sebanyak 30 ibu hamil di Puskesmas Pattingalloang dan 30 ibu hamil di Puskesmas Tamalate. Kemudian dilanjutkan dengan intervensi kedua dilakukan pada awal bulan Juni tahun 2018 yang terdiri dari 30 ibu hamil di Puskesmas Pattingalloang dan 30 ibu hamil di Puskesmas Tamalate. Kode etik penelitian ini tidak memaksakan kepada ibu hamil yang tidak mau ikut dalam penelitian, selain itu memanfaatkan bantuan instruktur yoga berpengalaman yang memiliki sertifikat mandiri dalam melakukan pelatihan senam prenatal yoga.

Pengukuran skor rerata dilakukan meng-

Tabel 1. Karakteristik Responden

\begin{tabular}{|c|c|c|c|c|c|c|}
\hline \multirow{2}{*}{ Karakteristik } & \multicolumn{2}{|c|}{ Intervensi } & \multicolumn{2}{|c|}{ Kontrol } & \multicolumn{2}{|c|}{ Total } \\
\hline & $n=60$ & $\%$ & $n=60$ & $\%$ & $n=120$ & $\%$ \\
\hline \multicolumn{7}{|c|}{ Kelompok Umur Ibu (tahun) } \\
\hline Remaja Akhir (17-25) & 25 & 41,7 & 22 & 36,7 & 47 & 39,2 \\
\hline Dewasa Awal (26-35) & 35 & 58,3 & 38 & 63,3 & 73 & 60,8 \\
\hline \multicolumn{7}{|l|}{ Tekanan darah diastole } \\
\hline $60-79 \mathrm{mmHg}$ & 26 & 43,3 & 28 & 46,7 & 54 & 45,0 \\
\hline $80-89 \mathrm{mmHg}$ & 29 & 48,3 & 31 & 51,7 & 60 & 50,0 \\
\hline $90-99 \mathrm{mmHg}$ & 5 & 8,3 & 1 & 1,7 & 6 & 5,0 \\
\hline \multicolumn{7}{|l|}{ Usia Kehamilan } \\
\hline 7 Bulan & 31 & 51,7 & 26 & 43,3 & 57 & 47,5 \\
\hline 8 Bulan & 23 & 38,3 & 24 & 40,0 & 47 & 39,2 \\
\hline 9 Bulan & 6 & 10,0 & 10 & 16,7 & 16 & 13,3 \\
\hline \multicolumn{7}{|l|}{ Paritas } \\
\hline 1 kali & 19 & 31,7 & 25 & 41,7 & 44 & 36,7 \\
\hline 2-4 kali & 39 & 65,0 & 34 & 56,7 & 73 & 60,8 \\
\hline$\geq 5$ kali & 2 & 3,3 & 1 & 1,7 & 3 & 2,5 \\
\hline \multicolumn{7}{|l|}{ Pendidikan Terakhir } \\
\hline SD & 9 & 15,0 & 5 & 8,3 & 14 & 11,7 \\
\hline SMP & 19 & 31,7 & 14 & 23,3 & 33 & 27,5 \\
\hline SMA & 27 & 45,0 & 25 & 43,4 & 53 & 44,1 \\
\hline Perguruan Tinggi & 5 & 8,3 & 15 & 25,0 & 20 & 16,7 \\
\hline \multicolumn{7}{|l|}{ Jenis Pekerjaan } \\
\hline PNS/honorer & 0 & 0,0 & 8 & 13,3 & 8 & 6,7 \\
\hline Pegawai Swasta & 3 & 5,0 & 2 & 3,3 & 5 & 4,2 \\
\hline Wiraswasta & 5 & 8,3 & 4 & 6,7 & 9 & 7,5 \\
\hline Polwan & 1 & 1,7 & 0 & 0 & 1 & 0,8 \\
\hline IRT & 51 & 85,0 & 46 & 76,7 & 97 & 80,8 \\
\hline
\end{tabular}


Tabel 2. Distribusi Hasil Pre-Test dan Post Test Tingkat Kecemasan Ibu Hamil Trimester III

\begin{tabular}{lcccccc}
\hline \multirow{2}{*}{ Tingkat Kecemasan } & \multicolumn{2}{c}{ Intervensi } & \multicolumn{2}{c}{ Kontrol } & \multicolumn{2}{c}{ Total } \\
\cline { 2 - 7 } & $\mathbf{n}=\mathbf{6 0}$ & $\mathbf{\%}$ & $\mathbf{n = 6 0}$ & $\mathbf{\%}$ & $\mathbf{n}=\mathbf{1 2 0}$ & $\mathbf{\%}$ \\
\hline Pre Test & & & & & & \\
Tidak Cemas & 3 & 5,0 & 7 & 11,7 & 10 & 8,3 \\
$\quad$ Cemas Ringan & 10 & 16,7 & 11 & 18,3 & 21 & 17,5 \\
$\quad$ Cemas Sedang & 30 & 50,0 & 24 & 40,0 & 54 & 45,0 \\
$\quad$ Cemas Berat & 17 & 28,3 & 18 & 30,0 & 35 & 29,2 \\
Post Test & & & & & & \\
Tidak Cemas & 6 & 10,0 & 3 & 5,0 & 9 & 7,5 \\
$\quad$ Cemas Ringan & 38 & 61,7 & 18 & 30,0 & 55 & 45,8 \\
Cemas Sedang & 15 & 25,0 & 27 & 45,0 & 42 & 35,0 \\
$\quad$ Cemas Berat & 2 & 3,3 & 12 & 20,0 & 14 & 11,7 \\
\hline
\end{tabular}

Tabel 3. Hasil Uji Test Normalitas Tingkat Kecemasan Ibu Hamil Trimester III

\begin{tabular}{lcccc}
\hline \multirow{2}{*}{ Tingkat Kecemasan } & \multicolumn{3}{c}{ Kolmogorov-Smirnov $^{a}$} \\
\cline { 3 - 5 } & & Statistic & df & Sig. \\
\hline \multirow{2}{*}{ Pre test } & Intervensi & 0,153 & 60 & 0,001 \\
& Kost test & 0,115 & 60 & 0,047 \\
& Intervensi & 0,115 & 60 & 0,046 \\
& Kontrol & 0,090 & 60 & 0,200 \\
\hline
\end{tabular}

${ }^{\mathrm{a}}$ Lilliefors Significance Correction

gunakan kuesioner yang diisi oleh ibu hamil sebelum intervensi pada awal penelitian sebagai hasil pre-test sedangkan pengukuran post-test diberikan kepada ibu hamil seminggu setelah dilakukan intervensi. Pelaksanaan pengukuran ini dilakukan pada kelompok intervensi serta kelompok yang tidak diberikan intervensi (kontrol). Analisis data meliputi hasil pengukuran skor rerata melalui pengujian Wilcoxon Signed Rank Test dan Mann Whitney U Test. Pengujian Wilcoxon Signed Rank Test untuk mengetahui perbedaan skor rerata sebelum dan sesudah dilakukan intervensi pada kelompok intervensi dan kelompok kontrol. Sedangkan Mann Whitney U Test untuk mengetahui perbedaan skor rerata kecemasan pada kelompok intervensi serta kelompok kontrol pada awal dan akhir penelitian sehingga dapat diperoleh perbedaan yang signifikan yang ditunjukkan oleh nilai $\mathrm{p}<0,05$.

\section{HASIL}

Tabel 1 menunjukkan bahwa untukkelompok intervensi, paling banyak pada kelompok umur dewasa awal (26-35 tahun) yaitu 58,3\%, begitupun pada kelompok kontrol paling banyak pada kelompok umur dewasa awal (26-35 tahun) juga yakni $63,3 \%$. Dilihat dari tekanan darah diastol, baik pada kelompok intervensi maupun kelompok yang tidak mendapat intervensi menunjukkan tekanan darah diastol paling banyak pada kisaran $80-89 \mathrm{mmHg}$ yaitu 48,3\% untuk kelompok intervensi dan 51,7\% untuk kelompok kontrol. Usia kehamilan dalam penelitian ini lebih banyak pada usia kehamilan 7 bulan yaitu $51,7 \%$ pada kelompok Intervensi dan 43,3\% pada kelompok kontrol. Pendidikan terakhir menunjukkan bahwa kebanyakan responden merupakan tamatan SMA yaitu $45,0 \%$ pada kelompok Intervensi dan $43,4 \%$ pada kelompok kontrol. Karakteristik pekerjaan kelompok intervensi dan kontrol lebih banyak bekerja sebagai IRT yakni masing-masing $85,0 \%$ dan 76,7\%. Begitupun secara keseluruhan responden paling banyak bekerja sebagai IRT yakni $80,8 \%$ dan paling sedikit bekerja sebagai polwan $0,8 \%$ serta wiraswasta $4,2 \%$

Tabel 2 menunjukkan bahwa pada awal penelitian (pre-test) baik kelompok intervensi maupun kelompok kontrol sama-sama menunjukkan tingkat kecemasan sedang yang paling tinggi dengan presentase total yaitu $45 \%$. Ibu hamil yang memiliki tingkat kecemasan sedang pada kelompok intervensi sebesar 50,0\% lebih tinggi dari 
Tabel 4. Perbandingan Rerata Tingkat Kecemasan Awal dan Akhir Ibu Hamil Trimester III pada Kelompok Intervensi dan Kelompok Kontrol

\begin{tabular}{llcc}
\hline \multicolumn{1}{c}{$\begin{array}{c}\text { Kelompok } \\
\text { Penelitian }\end{array}$} & \multicolumn{1}{c}{ Variabel } & Rerata \pm s.d. & $\mathbf{p}^{*}$ \\
\hline Intervensi & Tingkat Kecemasan Awal & $24,47 \pm 5,85$ & 0,000 \\
& Tingkat Kecemasan Akhir & $18,23 \pm 4,80$ & \\
Kontrol & Tingkat Kecemasan Awal & $24,03 \pm 1,70$ & 0,162 \\
& Tingkat Kecemasan Akhir & $23,07 \pm 2,25$ & \\
\hline
\end{tabular}

"Wilcoxon Signed Rank Test

Tabel 5. Perbandingan Rerata Tingkat Kecemasan Ibu Hamil Trimester III Sebelum dan Sesudah Intervensi

\begin{tabular}{lcc}
\hline \multicolumn{1}{c}{ Kelompok } & Mean Rank & $\mathbf{p}^{*}$ \\
\hline Sebelum Intervensi & & \\
$\quad$ Intervensi & 62,01 & 0,634 \\
$\quad$ Kontrol & 58,99 & \\
Sesudah Intervensi & & \\
$\quad$ Intervensi & 47,68 & 0,000 \\
$\quad$ Kontrol & 73,32 & \\
\hline
\end{tabular}

"Mann Whitney U Test

kelompok kontrol yaitu sebesar 40,0\%. Tabel 2 juga menunjukkan tingkat kecemasan pada akhir penelitian (post-test) di kelompok intervensi lebih banyak pada tingkat kecemasan ringan yaitu sebesar $61,7 \%$ berbeda dengan kelompok kontrol masih lebih banyak pada tingkat kecemasan sedang, yaitu sebesar $45,0 \%$.

Tabel 3 menunjukkan bahwa nilai signifikan pada awal penelitian (pre-test) didapatkan nilai $p$ yang kurang dari 0,05 yaitu 0,001 untuk kelompok yang diberi intevensi dan nilai $p$ sebesar 0,047 untuk kelompok yang tidak mendapatkan intervensi. Begitupun pada akhir penelitian (post-test) diperoleh nilai signifikansi kurang dari 0,05 untuk kelompok intervensi yaitu 0,046. Artinya kelompok intervensi dan kontrol pada awal penelitian serta kelompok intervensi pada akhir penelitian mempunyai sebaran data yang tidak normal. Berbeda dengan nilai signifikansi kelompok kontrol pada akhir penelitian (post-test) yang mendapatkan nilai signifikansi lebih dari 0,05 yaitu 0,200 yang artinya kelompok kontrol pada akhir penelitian mempunyai sebaran normal. Hal ini menunjukkan bahwa analisis yang digunakan adalah analisis non parametrik karena sebagian besar data tidak terdistribusi normal.

Tabel 4 menunjukkan hasil analisis dengan menggunakan Wilcoxon Signed Rank
Test didapatkan nilai signifikansi $0,000(\mathrm{p}<0,05)$ untuk kelompok intervensi artinya terdapat perbedaan rerata perhitungan tingkat kecemasan pada awal dan akhir penelitian sedangkan pada kelompok kontrol didapatkan nilai signifikansi $0,162(p>0,05)$ sehingga tidak terdapat perbedaan kecemasan pada kelompok kontrol. Tabel 5 menunjukkan hasil analisis dengan menggunakan Mann Whitney U Test. Sebelum intervensi didapatkan nilai signifikansi $0,634(\mathrm{p}>0,05)$ artinya tidak ada perbedaan rerata tingkat kecemasan antara kelompok intervensi dan kelompok kontrol, tetapi sesudah intervensi didapatkan nilai signifikansi $0,000(p<0,05)$, artinya terdapat perbedaan rerata tingkat kecemasan yang signifikan antara kelompok intervensi senam prenatal yoga dan kelompok kontrol

\section{PEMBAHASAN}

Karakteristik responden memberikan gambaran tentang kelompok umur, tekanan darah diastol, usia kehamilan, paritas, pendidikan terakhir, dan jenis pekerjaan. Hasil penelitian ini menunjukkan bahwa ibu hamil pada kelompok intervensi lebih banyak pada kelompok umur dewasa awal (26-35 tahun) sebesar 58,3\%, begitupun pada kelompok kontrol paling banyak pada kelompok umur dewasa awal (26-35 tahun) 
sebesar 63,3\%. Penelitian ini sejalan dengan penelitian Putri yang mendapatkan bahwa ibu hamil lebih banyak pada kelompok umur dewasa awal (26-35 tahun) sebesar 75\%. ${ }^{13}$

Distribusi responden berdasarkan tekanan darah diastol menunjukkan bahwa kebanyakan responden berada pada kelompok tekanan darah diastol yaitu $80-89$ mmHG sebesar $50 \%$. Hal ini menunjukkan bahwa rata-rata tekanan darah ibu hamil masuk dalam kategori prehipertensi.

Usia kehamilan paling banyak dalam penelitian ini adalah 7 bulan sebesar $47,5 \%$. Hal ini menunjukkan bahwa rata-rata ibu hamil yang ikut dalam penelitian ini merupakan ibu hamil yang memiliki usia kehamilan sekitar 28 minggu. Usia kehamilan pada penelitian ini merupakan usia kehamilan awal pada trimester III.

Distribusi responden berdasarkan paritas menunjukkan bahwa pada penelitian ini kebanyakan responden memiliki paritas 2-4 kali (multipara) sebesar $60,8 \%$. Penelitian ini berbeda dengan hasil yang diperoleh Rusmita kebanyakan responden tidak memiliki riwayat paritas (nullipara) sebesar $60,4 \% .^{7}$ Begitupun hasil penelitian Sari kebanyakan responden memiliki riwayat paritas nullipara sebesar 79,2\%. ${ }^{14}$

Pendidikan terakhir pada penelitian ini menunjukkan bahwa kebanyakan responden memiliki pendidikan yang tinggi, yaitu sebesar $60,8 \%$ untuk tingkat SMA dan PT. Penelitian ini sejalan dengan hasil yang diperoleh Rusmita kebanyakan responden memiliki pendidikan yang tinggi, yaitu SMA dan PT sebesar 96,9\%.7

Distribusi menurut pekerjaan menunjukkan bahwa kebanyakan responden ibu hamil memiliki pekerjaan sebagai IRT sebesar $80,8 \%$. Hasil ini sejalan Rafika terkait efektifitas prenatal yoga terhadap pengurangan keluhan fisik pada ibu hamil trimester III kebanyakan respondennya adalah ibu hamil yang tidak bekerja atau sebagai IRT sebesar $62,5 \%{ }^{15}$

Kecemasan adalah keadaan seseorang memiliki rasa gelisah atau cemas berlebih, serta aktivitas sistem saraf otonom yang merespon terhadap ancaman yang tidak jelas atau tidak spesifik. $^{16}$ Jika dihubungkan dengan kecemasan yang dialami ibu hamil dapat diartikan sebagai kecemasan yang dihadapi kembali ibu hamil yang dialami dirinya sendiri serta bayi dalam kandungan- nya yang dipengaruhi oleh pengalaman kehamilan yang dirasakan sebelumnya, kecemasan terkait status anak, kemampuan atau kesiapan keluarga, kesehatan ibu hamil, bahaya ancaman keguguran, bayi cacat, anak kembar, kelahiran prematur serta pandangan ibu tentang hal-hal lainnya seputar persalinan. ${ }^{17}$

Senam prenatal yoga sangat berperan penting dalam menurunkan tingkat kecemasan ibu hamil yang memasuki masa kehamilan trimester ketiga. Penelitian ini membuktikan bahwa pada awal penelitian banyak ibu hamil mengalami kecemasan sedang yaitu $50,0 \%$ pada kelompok intervensi dan $40,0 \%$ pada kelompok kontrol. Setelah dilakukan intervensi sebanyak dua kali untuk setiap ibu hamil terjadi perubahan besar pada tingkat kecemasan untuk kelompok intervensi terjadi perbedaan penurunan skor rerata yang signifikan $(p=0,000)$ sedangkan untuk kelompok kontrol perbedaan skor rerata tidak signifikan $(\mathrm{p}=0,162)$.

Hasil analisis dengan Mann Whitney U Test menunjukkan hasil yang signifikan $(\mathrm{p}=0,000)$ antara kelompok intervensi dan kelompok kontrol pada akhir penelitian. Hal ini menunjukkan bahwa senam yoga pada fase prenatal berpengaruh terhadap turunnya rasa cemas ibu hamil trimester ketiga di Puskesmas Pattingalloang dan Puskesmas Tamalate. Huberty menyatakan bahwa aktivitas fisik berupa senam prenatal yoga dapat mengurangi depresi ibu hamil yang berkaitan dengan kejadian kecemasan. ${ }^{18}$

Penelitian ini sejalan dengan penelitian Khalajzadeh, yang berhasil menunjukkan dengan latihan yoga pada trimester III memiliki dampak positif pada kecemasan perempuan. ${ }^{19}$ Selain itu, penelitian yang dilakukan oleh Larasati dan Sumiatik mengemukakan bahwa terdapat hubungan yang signifikan antara wanita hamil yang melakukan senam yoga dengan menurunnya kecemasan pada kehamilan. ${ }^{20,21}$

Yoga sangatdibutuhkan oleh ibuhamil untuk melunturkan persendian terutama ibu hamil yang sudah dekat proses persalinan. Latihan senam yoga terdiri dari lima teknik inti, yaitu teknik penguasaan tubuh (asana), teknik penguasaan napas (pranayama), teknik penguncian energi (bandha), teknik pengendalian energi (mudra), serta teknik pembersihan tubuh (kriya) yang dapat berman- 
faat selama masa kehamilan. ${ }^{22}$ Teknik ini diharapkan dapat meringankan keluhan ibu hamil selama kehamilan terutama terkait kram dan edema yang sering pada akhir kehamilan, memperlancar aliran darah serta nutrisi ke janin, membantu posisi bayi dan pergerakannya, meningkatkan energi serta nafsu makan, menciptakan ketenangan dan fokus, mengurasi perasaan mual, meredakan ketegangan di leher rahim, mengurangi ketegangan, cemas dan depresi selama hamil, merenggangkan otot-otot, membuat nyenyak tidur serta membantu mengurangi nyeri pinggang atau punggung bawah akibat peregangan otot-otot sekitar perut. ${ }^{23}$

Menurut Stoppard, yoga merupakan teknik yang terbaik dalam mempersiapkan proses persalinan karena menggunakan teknik latihan yang fokusnya menitikberatkan terhadap pengendalian otot, teknik relaksasi dan ketenangan pikiran. ${ }^{24} \mathrm{Hal}$ ini sejalan dengan penelitian Cramer, bahwa wanita hamil yang latihan yoga baik untuk kesehatan, sikap dan lingkungan sekitarnya. ${ }^{25} \mathrm{Be}-$ gitupun dengan hasil penelitian Rusmita menunjukkan bahwa ada hubungan yang signifikan $(p=0,014)$ senam hamil yoga terhadap kesiapan ibu hamil menghadapi persalinan di RSIA Limijati Bandung. ${ }^{7}$ Kesiapan ibu hamil baik secara fisik maupun mental dapat mengurangi kecemasan ibu hamil terkait persalinan yang akan dihadapi nantinya.

Senam prenatal yoga yang dilakukan pada ibu hamil di Puskesmas Pattingalloang dan Puskesmas Tamalate diselingi juga pendidikan kesehatan di setiap pertemuannya. Pendidikan kesehatan didalamnya termasuk pemahaman mengenai kesiapan ibu hamil menghadapi perubahan postur tubuh yang akan dialaminya, dijelaskan pula hal-hal apa saja yang perlu dilakukan ibu hamil terutama pemeriksaan kehamilan yang rutin, tablet tambah darah, penimbangan berat badan, imunisasi tetanus toxoid, serta saran makanan bergizi selama kehamilan. Selain itu ibu hamil diajarkan cara menjaga kesehatannya, yaitu memperhatikan kebersihan badan, mengurangi kerja yang berat dan senatiasa beristirahat minimal sejam pada siang hari serta hindari asap rokok dan minuman yang berbahaya bagi kesehatan janin. Ibu hamil juga diberi pengetahuan tentang tandatanda bahaya kehamilan meliputi perdarahan, bengkak yang berlebihan, demam tinggi, keluar air ketuban bukan pada waktunya, bayi kurang pergerakannya, muntah terus dan susah makan. Jadi melalui senam prenatal yoga ibu hamil telah diberi persiapan fisik dan mental berupa pengetahuan dan teknik dalam menghadapi kehamilan sehingga ibu hamil semakin tenang dan berkurang kecemasannya serta lebih siap dalam menghadapi persalinan nantinya

Berkaitan dengan hal tersebut, bidan sebagai tenaga kesehatan memiliki peranan penting terkait hal asuhan terhadap ibu-ibu dalam masa kehamilan. Bidan sebagai edukator memiliki peran penting dalam meningkatkan pengetahuan tentang kesehatan ibu hamil, sehingga terjadi perubahan perilaku. Peran bidan sebagai edukator dapat dilakukan melalui konsep kebidanan komplementer yaitu pelaksanaan senam hamil terutama prenatal yoga demi persiapan persalinan kedepannya.

\section{KESIMPULAN DAN SARAN}

Penelitian ini menyimpulkan bahwa intervensi senam yoga yang dilakukan pada tahap prenatal ibu hamil berpengaruh terhadap turunnya tingkat kecemasan pada ibu hamil yang memasuki fase trimester ketiga di Puskesmas Pattingalloang dan Puskesmas Tamalate Kota Makassar. Oleh karena itu, bidan sebagai edukator memiliki peranan yang penting selain memberikan pengetahuan kepada ibu hamil dapat diberi pelatihan senam prenatal yoga untuk persiapan persalinan ibu hamil. Selanjutnya saran bagi ibu hamil perlunya melakukan senam prenatal yoga guna mengurangi tingkat kecemasan dan sebagai persiapan fisik dan mental dalam menghadapi persalinan nantinya dan bagi petugas kesehatan Puskesmas Pattingalloang dan Puskesmas Tamalate Kota Makassar diharapkan dapat menfasilitasi ibu hamil dalam mendapatkan informasi terkait upaya mengatasi keluhan yang dihadapi selama masa kehamilan terutama cara penurunan kecemasan ibu hamil yang sudah mendekati persalinan.

\section{DAFTAR PUSTAKA}

1. Salafas, E., Anisa, R., Rusita, V. I. Efektifitas Hypno-EFT dan Pernafasan Yoga dalam Menurunkan Kecemasan Ibu Hamil di BPM Ny. Sri Kustinah. Jurnal Ilmiah Kebidanan. 2016;7(2):84-94. 
2. WHO. Maternal Mortality. http://www.who. int/mediacentre/ factsheets/fs348/en/. 2016. Diakses tanggal 27 Mei 2017.

3. Kemenkes RI. Profil Kesehatan Indonesia. Jakarta : Kemenkes RI; 2015.

4. Dinkes Sulsel. Profil Kesehatan Provinsi Sulawesi Selatan. Makassar : Dinkes Sulsel; 2016.

5. Puskesmas Pattingalloang Kota Makassar. Profil Puskesmas Pattingalloang Tahun 2017. Makassar : Puskesmas Pattingalloang; 2017.

6. Puskesmas Tamalate Kota Makassar. Profil Puskesmas Tamalate Tahun 2017. Makassar : Puskesmas Tamalate; 2017.

7. Rusmita, E. Pengaruh Senam Hamil Yoga Terhadap Kesiapan Ibu Hamil Menghadapi Persalinan Di RSIA Limijati Bandung. Jurnal Ilmu Keperawatan. 2015;3(2):80-86.

8. Mediarti, D., Sulaiman, Rosnani, Jawiah. Pengaruh Yoga Antenatal Terhadap Pengurangan Keluhan Ibu Hamil Trimester III. Jurnal Kedokteran dan Kesehatan. 2014;1(1):47-53.

9. Apriliani, R. A. Pengaruh Yoga Prenatal terhadap Kecemasan Sesaat dalam Menghadapi Persalinan pada Primigravida Trimester III Digalenia Mom and Baby Center Kota Bandung. Skripsi. Fakultas Psikologi Universitas Islam Bandung, Bandung; 2015.

10. Battle, C. L., Uebelacker, L. A., Magee, S. R., Sutton, K. A., Miller, I. W. Potential for Prenatal Yoga to Serve as an Intervention to Treat Depression During Pregnancy. Women's Health Issues : Official Publication of the Jacobs Institute of Women's Health. 2015;25(2):134-141.

11. Bershadsky, S., Trumpfheller, L., Kimble, H. B., Pipaloff, D., Yim, I. S. The Effect of Prenatal Hatha Yoga on Affect, Cortisol and Depressive Symptoms. Complementary Therapies in Clinical Practice. 2014;20(2):106-113.

12. Kinser, P. A., Goehler, L., Taylor, A. G. How Might Yoga Help Depression? A Neurobiological Perspective. Explore (New York, N.Y.). 2012;8(2):118-126.

13. Putri, S. A. Perbedaan Pemberian Senam Hamil dan Yoga terhadap Peningkatan Durasi Tidur Ibu Hamil Trimester III. Skripsi. Universitas Aisyiyah, Yogyakarta; 2016.

14. Sari, A. A., Puspitasari, D. Hubungan Senam
Yoga dengan Kesiapan Fisik dan Psikologis Ibu Hamil dalam Menghadapi Persalinan di kelas Antepartum Gentle Yoga Yogyakarta. Jurnal Terpadu Ilmu Kesehatan. 2016;5(2):207-211.

15. Rafika. Efektifitas Prenatal Yoga terhadap Pengurangan Keluhan Fisik pada Ibu Hamil Trimester III. Jurnal Kesehatan. 2018;9(1):8692.

16. Sadock, B. J. Kaplan \& Sadock's Comprehensive Textbook of Psychiatry. Lippincott Williams \& Wilkins Philadelphia, PA; 2000.

17. Maimunah, S. Kecemasan Ibu Hamil Menjelang Persalinan Pertama. Jurnal Humanity. 2009;5(1):61-67.

18. Huberty, J., Leiferman, J. A., Gold, K. J., Rowedder, L., Cacciatore, J., McClain, D. B. Physical activity and depressive symptoms after stillbirth: informing future interventions. BMC Pregnancy and Childbirth. 2014;14(1):391.

19. Khalajzadeh, M., Shojaei, M., Mirfaizi, M. The Effect of Yoga on Anxiety Among Pregnant Women in Second and Third Trimester of Pregnancy. Eur J Sport Sci. 2012;1(3):85-89.

20. Larasati, I. P. dan A. Wibowo. Pengaruh Keikutsertaan Senam Hamil terhadap Kecemasan Primigravida Trimester Ketiga dalam Menghadapi Persalinan. Jurnal Biometrika dan Kependudukan. 2012;1(1):6.

21. Sumiatik. Hubungan Senam Yoga dengan Mengurangi Kecemasan pada Kehamilan Trimester III di Klinik Halim Belawan. Jurnal Maternal dan Neonatal. 2016;1(1):8-14.

22. Indiarti, MT. Panduan Lengkap Kehamilan, Persalinan dan Perawatan Bayi. 10 ${ }^{\text {th }}$ ed. Yogyakarta: Diglossia Media; 2009.

23. Hariyanto, M. Pengaruh Senam Yoga terhadap Tingkat Kecemasan Ibu Hamil Trimester III di Praktik Bidan Mandiri Kabupaten Boyolali. Skripsi. Surakarta: Universitas Muhammadiyah; 2015.

24. Stoppard, M. Conception Pregnancy and Birth: Ensiklopedia Kehamilan. Surabaya: Erlangga; 2008.

25. Cramer, H., Frawley, J., Steel, A., Hall, H., Adams, J., Broom, A., Sibbritt, D. Characteristics of Women Who Practice Yoga in Different Locations During Pregnancy. BMJ open. 2015;5(8):1-7,e008641. 